\title{
Drip Fertigation Technology for Enhancing Date Palm Productivity and Fruit Quality
}

\author{
N. Th. Mazahrih ${ }^{1,2}$, A. S. Al Sayari ${ }^{3}$, S. A. Al Shamsi ${ }^{3} \&$ M. Ben Salah ${ }^{2}$ \\ ${ }^{1}$ National Center for Agricultural Research and Extension (NCARE), Amman, Jordan \\ ${ }^{2}$ International Center for Agricultural Research in Dry Area (ICARDA), UAE-Oman \\ ${ }^{3}$ Ministry of Climate Change \& Environment, Dubai, UAE \\ Correspondence: M. Ben Salah, Date palm project Regional coordinator in GCC countries, ICARDA, Oman. Tel: \\ 963-212-213-433. E-mail: m.ben-salah@cgiar.org
}

\author{
Received: March 4, $2018 \quad$ Accepted: August 9, $2018 \quad$ Online Published: October 15, 2018 \\ doi:10.5539/jas.v10n11p380 URL: https://doi.org/10.5539/jas.v10n11p380
}

The research is financed by the Gulf Cooperation Council.

\begin{abstract}
A field experiment was conducted during two successive growing seasons, 2014/2015 and 2015/2016 to evaluate the effect of different fertilizer application methods on date palm (Phoenix dactylifera $\mathrm{L}$.) yield and fruit quality grown in sandy soil. Strip block statistical design with three replicates was used on four selected date palm cultivars (Madjool, Sacchari, Kheyarah and Sggaa) as main treatments and three fertilizer application methods (Hydraulic injector, Surface Broadcast and By-pass tank) as sub main treatments. The results revealed significant increases in yield and fruit quality when using continuous fertigation by Hydraulic injector comparing with broadcast and By-pass tank traditional methods. The average of two seasons results indicated also that using Hydraulic injector method maximized Sacchari date yield by producing $69 \mathrm{~kg}$ per tree and resulted in the best water productivity $\left(1.06 \mathrm{~kg} \mathrm{~m}^{-3}\right)$. The use of fertigation method has significantly increased the date palm productivity by $81,51.2,66.7$ and $72.8 \%$ in comparison to the traditional Surface Broadcast method for Madjool, Sacchari, Kheyarah and Sggaa, respectively. The mean fruit weights were significantly increased by 56.5, 72.1, 90.2 and $68.8 \%$ when using the hydraulic injector compared to the traditional broadcast application method for pervious date palm cultivars, respectively.
\end{abstract}

Keywords: Phoenix dactylifera L., Hydraulic injector, Surface Broadcast, By-pass tank, water productivity

\section{Introduction}

Water and nutrients are the most crucial inputs for date palm cultivation and their application through micro irrigation systems is very important as a mean of increasing land, water and fertilizer use efficiency (Papadopoulos, 1997a). The main challenges facing the agriculture development in arid regions are water, land and aridity as well as the efficient way to provide crops with an optimal quantity of water and nutrients throughout the growing season. Fertigation is considered the solution to this challenge, whereby both water and fertilizers are delivered to crops simultaneously through the irrigation system. Scheduling fertilizer applications on the basis of needs reduces nutrient losses compared to conventional application methods that depend on the soil as a reservoir for nutrients (Priya et al., 2017). The method of fertilizer application also improves the use efficiency of nutrients (Zotarelli et al., 2009). Well-balanced fertigation program will satisfy the exact needs of the plant as they change along the season, increase efficient use of water and fertilizers, increase yield, protect the environment and sustain irrigated agriculture.

The Arabian Peninsula is considered as the original home of date palm trees which one of the oldest fruit tree known in the region and over thousands of years this tree played an important role in the lives of the people since long time where the farmers gained experience which allowed them to invest in the whole of tree parts including the fruits, leaves and stalks. The date palm had a special care by official and personal attention at the highest levels in the United Arab Emirates (UAE) which made date palm privileged position. A tremendous growth in the number of date palm trees and date production and encourage farmers to reach the number of 42 million trees 
(Jaradat \& Zaid, 2004). Zaid and de Wet (2002) recommended to add $0.650 \mathrm{~kg}$ of Nitrogen (N), $0.650 \mathrm{~kg}$ of Phosphorus $(\mathrm{P})$ and $0.870 \mathrm{~kg}$ of Potassium $(\mathrm{K})$ of fertilizer elements yearly per tree to produce $50 \mathrm{~kg}$ of dates.

Fertigation provides $\mathrm{N}, \mathrm{P}$ and $\mathrm{K}$ as well as essential nutrients directly to the active root zone. This minimizes the loss of nutrients and helps in improving productivity and quality of farm produce. Ashwani (2001) reported that the adoption of fertigation worldwide has showed favorable results in terms of fertilizer use efficiency and the quality of product. Proper scheduling and intervals are also needed to provide nutrients at a time when plants require them. The performance of the crop may vary with the application rates and schedule of irrigation. Fares and Abbas (2009) conducted studies on the injection rates and components of a fertigation system. Accurate chemical application and easy adaptation for automation are the major advantages of fertigation equipment. The amount of fertilizer injected into the system (suction rate) and motive flow rate is very important for proper crop production. Al-Qurashi et al. (2015) concluded that fertilization is critical to increase yield of young tissue culture-regenerated palms in Saudi Arabia. Drip fertigation (application of fertilizer with drip irrigation), on the other hand, has proved its superiority over conventional method of fertilizer application to ensuring the right amounts of irrigation water and plant nutrients available at the root zone and nourishes the crop requirements for stabilizing yield and quality of produce (Patel \& Rajput, 2004).

Deficiency of N, P and K is a major production constraint in sandy soils, which have inherent constraints like $\mathrm{P}$ fixation, rapid hydraulic conductivity, faster infiltration rate, leaching of basic cations and low CEC (Patel, 2017). Hence, the cultivated crop in this soil requires large quantity of nutrients to support its growth and yield. Considering the soil and crop constraints, fertilizers should be applied in synchrony with crop demand in smaller quantities during the growing season.

Yield responses to the time of $\mathrm{N}$ and $\mathrm{K}$ application, either per plant only or per plant with fertigation, were dependent upon soil type (Locascio et al., 1989). Fertilizer use efficiency under different methods of fertilizers application as reported by Patel (2017) in India for N nutrient are 30-50 and 95\%, for P are 20 and $45 \%$, for K 50 and $80 \%$ when using Broadcasting and fertigation application methods, respectively.

The UAE is characterized by scarcity of water resources and the deterioration of their quality, unregulated use of water for irrigation and fertilizer, the negative impact of fertilizers application on the environment as a result of unregulated use of fertilizers and low awareness among farmers regarding the importance irrigation water and fertilizers management. Most farmers in the UAE used to fertilize palm trees by two methods, either broadcasting by spreading the fertilizers in the basin of the tree or by using the traditional by- pass tank fertigator The fertigation technique is used mainly with $\mathrm{N}, \mathrm{P}$ and $\mathrm{K}$ mineral fertilizers using traditional methods, whereas, little data have been reported concerning the fertigation using injection methods. So this study aimed to evaluate the effect of three fertilizers application methods on yield quantity and quality of four date palm cultivars (Sacchari, Madjool, Sggaa and Kheyarah) under UAE conditions.

\section{Materials and Methods}

\subsection{Location and Duration of the Study}

This experiment trail was investigated at Hamrania Agricultural Research Station, in the Northern Region, UAE (latitude $25.6^{\circ} \mathrm{N}$, longitude $55.9^{\circ} \mathrm{E}$ ). The experimental site is located in arid climate with generally light and erratic precipitation. The soil is classified as sandy and considered marginally suitable for various crop production systems under strict management conditions. The study was carried out during the 2014/2015 and 2015/2016 growing seasons on 9-year-old date palm trees.

\subsection{Experimental Design}

Strip-Block design with three replicates (four palms/replicate) was used to study the effect of fertilization methods on four widely grown date palm cultivars in UAE using three fertilizers application methods (Figure 1). Date palm cultivars used as the main treatments in the study were Madjool, Sacchari, Sggaa and Kheyarah. Annually $20 \mathrm{~kg}$ tree $^{-1}$ organic manure was added in December, while chemical fertilizers were added according to recommended application in the UAE ( $1 \mathrm{~kg}$ of N, $0.5 \mathrm{~kg}$ P and $1.5 \mathrm{~kg}$ per tree annually) using compound fertilizer $\left(20 \mathrm{~N}: 20 \mathrm{P}_{2} \mathrm{O}_{5}\right.$ : $20 \mathrm{~K}_{2} \mathrm{O}$ ), Potassium Nitrate, Calcium nitrate and mixture of microelements while phosphoric acid (85\%) formed the source of water soluble fertilizers in fertigation treatments. The following methods of fertilizer application are used as sub main treatments:

1) Fertilizer application continuously by hydraulic injector (Dezetron);

2) Fertilizer application manually by using Surface Broadcast method on the soil surface (three times a year; Feb, Mar and May). Each fertilizer treatment was applied at one meter away from the date palm trunk and then irrigated directly after addition of the fertilizer treatments; 
3) Fertilizer application by conventional by-pass tank.

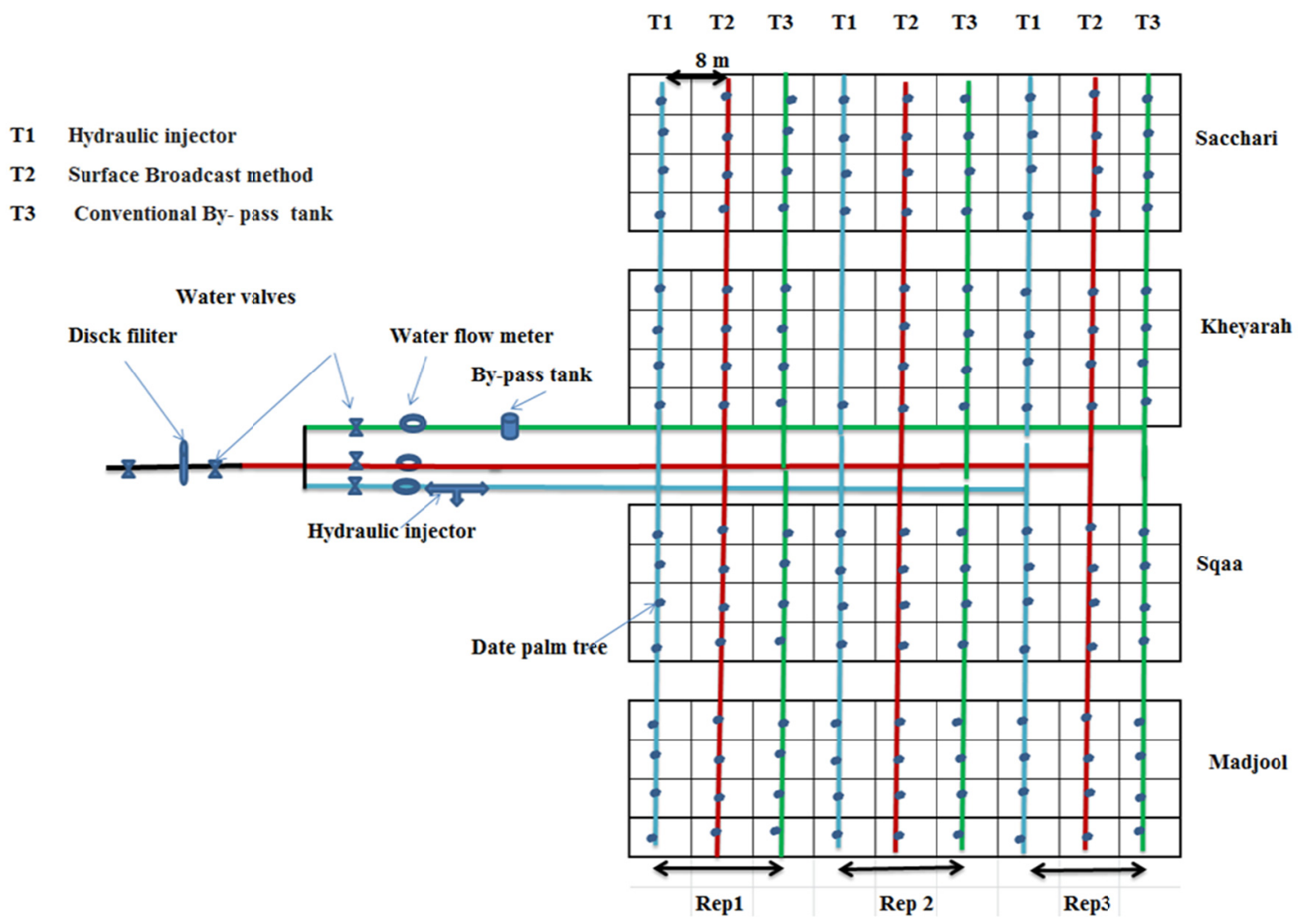

Figure 1. Fertigation experiment layout at Hamrania research station

\subsection{Soil and Irrigation Water Analysis}

Four compound soil samples were randomly collected from the experimental site and analyzed (Electrical Conductivity (EC), pH, Na, $\mathrm{P}, \mathrm{K}, \mathrm{Cl}, \mathrm{Fe}, \mathrm{Zn}$ and $\mathrm{Mn}$.) from 0-50 m depths from four locations to represent the soil initial conditions before starting the fertigation experiment. At the end of each growing season, the soil samples were collected from each treatment site to measure the effect of the fertigation treatment on the soil chemical prosperities. Irrigation water application is $100 \%$ of the estimated crop water requirement for all experimental treatments which has been calculated based on the climate data that has been collected for number of years using Irrigation water applications based on estimated daily water requirement by the Penman-Montieth equation (Allen et al., 1998) and Crop Coefficients ( $\mathrm{kc}$ ) for mature date palm in UAE ( $\mathrm{kc}=0.7,0.73,0.8,0.9$, 0.9. 0.9, 0.9, 0.9, 0.85, 0.75, 0.73 and 0.7 during Jan, Feb, Mar, Apr, May, June, July, Aug, Sep, Oct, Nov and Dec, respectively) (Bazza, 2008). Irrigation scheduling has identified depending on soil properties and plant growth stages. Due to sandy soil texture and irrigation water salinity the irrigation was scheduled in a rate of three irrigations per day from groundwater using drip irrigation system (two rings from Polyethylene GR pipe were installed at each tree with 35 emitters of 4lph discharge of each emitter). The results of the soil and irrigation water analyses are presented in Table 1. 
Table 1. Some soil ( $0.50 \mathrm{~m}$ depth) and irrigation water chemical properties of the experimental site

\begin{tabular}{lll}
\hline Items & Soil & Irrigation Water \\
\hline $\mathrm{EC}\left(\mathrm{dc} \mathrm{m}^{-1}\right)$ & 7.3 & 4.9 \\
$\mathrm{pH}$ & 7.8 & 7.3 \\
$\mathrm{Na}(\mathrm{ppm})$ & 799.6 & 626.0 \\
$\mathrm{Cl}(\mathrm{ppm})$ & 1788.0 & 993.5 \\
$\mathrm{~K}(\mathrm{ppm})$ & 146.9 & 15.3 \\
$\mathrm{Fe}(\mathrm{ppm})$ & 133.1 & 0.2 \\
$\mathrm{Zn}(\mathrm{ppm})$ & 2.5 & 0.0 \\
$\mathrm{Mn}(\mathrm{ppm})$ & 11.0 & 0.1 \\
\hline
\end{tabular}

\subsection{Plant Data Collections}

Palm trees were planted at space $8 \times 8 \mathrm{~m}$ apart. Selected trees were as uniform as possible in growth and vigor and free from insect's damage and diseases. All the routine agro-technical operations were carried out according to the traditional schedule for date palm plantation. Fruit thinning was done with extra clusters deletion regarding the ratio of 8 leaves to 1 cluster in the Kimri stage (fruits are hard and crisp and bright green in color). Total yield per tree in the two seasons was determined by harvesting eight bunches from each tree and the weights were recorded in kilogram. Pinnae (leaflets) samples (14 leaflets/palm) were randomly collected in April for NPK determinations. The samples were collected from the middle part of fully expanded leaves which bear the fruit bunches in their axiles around the head of each tree at early beginning of the Bisr stage. Samples of 30 full mature fruits were randomly selected from each palm at harvesting stage in the mid of October for determination of the fruit average weight, total sugar percentage and chemical characteristics such as $\mathrm{N}, \mathrm{P}$ and $\mathrm{K}$ contents were measured in laboratory. Obtained raw data were statistically analyzed. Means were compared using a least significant difference (L.S.D.) test at the 0.05 significance level via MSTATC software.

\section{Results and Discussion}

\subsection{Date Palm Yield and Water Productivity}

The results obtained clearly indicated that all tested fertigation treatments (Hydraulic injector and By-pass tank) significantly increased the yield, average fruit weight and water productivity compared with the control (Broadcasting) in 2015 and 2016 growing seasons (Table 2).

For all date palm cultivars, the results showed that the yields were higher with the applications fertilizer using Hydraulic injector than with using the Broadcasting and By-pass tank methods in both studied growing seasons. It is noted in Table 2 that the method of fertilization using Hydraulic injector has significantly exceeded the conventional methods. The average rate of production of all date palm cultivars in the study increased by $74 \%$ compared with the use of the Surface Broadcast and by $28 \%$ compared with the By-pass tank. These results confirm the previous studies of El Zuraiqi et al. (2004) who indicated that fertigation increased the yield and Nitrogen Use Efficiency (NUE) by 2 to 3 times than Surface Broadcast method.

Fertilizers are more efficiently used when mixed with irrigation water and applied with drip-irrigation systems than when spread on the ground and then irrigated, in which case more fertilizer is lost by leaching past the root zone. When combined with an efficient irrigation system, both nutrients and water can be manipulated and managed to obtain the maximum possible yield of marketable production from a given quantity of these inputs (NSW Department of Primary Industries, 2005).

The obtained results during 2015 and 2016 growing seasons indicated that the highest yield was recorded for Sacchari cultivar of 67.3 and $70.6 \mathrm{~kg}^{-1} \mathrm{e}^{-1}$ by using the Hydraulic injector fertigation method for the two growing seasons, respectively. While the lowest yield was $27.8 \mathrm{~kg}^{-1} \mathrm{e}^{-1}$ in 2015 for Kheyarah and $25 \mathrm{~kg} \mathrm{tree}^{-1}$ in 2016 for Sggaa cultivars when using the Surface Broadcast method. Comparing the average production of the two seasons of the studied date palm cultivars using the different fertilization methods, the production of the Sacchari, Madjool, Sggaa and Keyarah increased by 81, 51.2, 66.7 and $72.8 \%$ when Hydraulic injector was used compared with the use of Surface Broadcast method and by 29.2, 19.3, 27.5 and 28.9\% when using By-pass tank for the previous cultivars, respectively. There were significant differences in the effect of fertilization methods and cultivars on the quality of fruits, where the highest average weight of the fruit of the Madjool was $22.2 \mathrm{~g}$, superior to the rest of the cultivars when using hydraulic injector. The highest yield was achieved in response to fertilization methods, where the average fruits weights were increased by 56.5, 72.1, 90.2 and $68.8 \%$ when the 
hydraulic injection was used compared with the Surface Broadcast and 9.3, 60, 32 and 15\% when using By-pass tank for the previous cultivars, respectively. The average water productivity in both seasons also affected by the fertigation methods, results showed in Table 2 that the highest water productivity in 2015 and 2016 growing seasons were 1.04 and $1.07 \mathrm{~kg} \mathrm{~m}^{-3}$ were recorded for the Sacchari when using the hydraulic injector, while the lowest values were recorded in 2015 season $\left(0.43 \mathrm{~kg} \mathrm{~m}^{-3}\right)$ and in $2016\left(0.4 \mathrm{~kg} \mathrm{~m}^{-3}\right)$ when using the Broadcasting method for Kheyarah and Sggaa cultivars, respectively. The increments in yield by adding fertilizers using the fertigation method may be due to the fact that efficient distribution of nutrients distribution especially for $\mathrm{N}$ and $\mathrm{K}$. The $\mathrm{N}$ is the basic protein building unit and protein is the basic cell building unit and involved in many physiological processes (Idris et al., 2012). Similar results were reported by Al-Qurashi (2015) who recommended to apply with small amount of fertilizers every irrigation time for better efficient use. Available $\mathrm{K}$ is also increased under fertigation treatments for date palms.

Table 2. Date palm yield, fruit weight and water productivity for the selected cultivars under fertilization methods during two growing seasons

\begin{tabular}{|c|c|c|c|c|c|c|c|}
\hline \multirow{2}{*}{ Cultivars } & \multirow{2}{*}{ Fertilization methods } & \multicolumn{2}{|c|}{ Yield $\left(\mathrm{kg}\right.$ tree $\left.^{-1}\right)$} & \multicolumn{2}{|c|}{ Fruit weight $(\mathrm{g})$} & \multicolumn{2}{|c|}{ Water productivity $\left(\mathrm{kg} \mathrm{m}^{-3}\right)$} \\
\hline & & 2015 & 2016 & 2015 & 2016 & 2015 & 2016 \\
\hline \multirow[t]{3}{*}{ Sacchari } & Hydraulic Injector & 67.3 & 70.6 & 15.2 & 16.6 & 1.04 & 1.07 \\
\hline & Surface Broadcast & 38.1 & 38.1 & 11.0 & 9.5 & 0.59 & 0.60 \\
\hline & By-pass tank & 57.4 & 50.0 & 15.2 & 14.0 & 0.88 & 0.87 \\
\hline \multirow[t]{3}{*}{ Kheyarah } & Hydraulic Injector & 42.6 & 40.4 & 15.4 & 10.9 & 0.66 & 0.63 \\
\hline & Surface Broadcast & 27.8 & 27.1 & 6.9 & 9.0 & 0.43 & 0.40 \\
\hline & By-pass tank & 34.8 & 34.8 & 7.5 & 9.5 & 0.54 & 0.53 \\
\hline \multirow[t]{3}{*}{ Sggaa } & Hydraulic Injector & 55.3 & 36.8 & 15.6 & 15.2 & 0.85 & 0.57 \\
\hline & Surface Broadcast & 29.7 & 25.0 & 6.7 & 10.3 & 0.46 & 0.40 \\
\hline & By-pass tank & 39.5 & 32.0 & 10.6 & 13.0 & 0.61 & 0.47 \\
\hline \multirow[t]{4}{*}{ Madjool } & Hydraulic Injector & 53.3 & 56.6 & 23.6 & 20.8 & 0.82 & 0.87 \\
\hline & Surface Broadcast & 30.1 & 33.6 & 12.1 & 14.6 & 0.46 & 0.50 \\
\hline & By-pass tank & 39.5 & 46.1 & 19.3 & 19.3 & 0.61 & 0.70 \\
\hline & $\operatorname{LSD}(\mathrm{P}=0.05)$ & 10.7 & 8.2 & 2.35 & 0.74 & 0.16 & 0.12 \\
\hline
\end{tabular}

The increase in the productivity and growth of palm and the quality of the fruit when using the Hydraulic injector are due to two reasons, first because this fertilization method is apply in a systematic manner to meet the plant nutrients requirement where the homogeneity of the solution providing plant roots with nutients more than from the other two methods. The use of By-pass tank does not give nutrients to the plant regularly where the concentration of fertilizer was high in the beginning of irrigation and very low at the end, as well as the method of the Surface Broadcast where the fertilizers were added during the year at three batches only, most of it lost by air or washed with irrigation as deep percolation. The other reason is due to the sandy soil texture which has a very low holding capacity of preservation of both nutrients and water, where it is might washed away from the root zone at the time by irrigation. These results are in line with Neelam and Rajput (2005) foundation who reported that the highest yield was recorded in daily fertigation followed by alternate day fertigation and weekly fertigation while the lowest was recorded in monthly fertigation.

The data from both seasons also indicated that the fruit weight was higher with the fertilizer application using Hydraulic injector than with using traditional Broadcasting and By-pass tank methods for all studied date palm cultivars. However, there was no significant differences in fruit weight between the two seasons.

\subsection{Nutrient Concentration in Soil Samples}

The N, P and $\mathrm{K}$ nutrients concentration in the soil layer $(0.0-50 \mathrm{~cm})$ before starting the experiment and at the end of 2015 growing season are presented in Figure 2. Continuous small applications of soluble nutrients using the Hydraulic injector, particularly in sandy soils, result in more uniform distribution of nutrients applications and other chemicals around plant roots, that enhance the rate of nutrient uptake by the plants which significantly increased the yield. These insignificant differences for NPK in the soil among treatments could be attributed to the unfavorable soil conditions including high soil salinity, high level of Sodium, Chlorine and high irrigation water salinity. The less nutrients availability in conventional treatment especially $\mathrm{P}$ and $\mathrm{K}$ might be due to the nature of their mobility beside the presence of salts in the experimental soil. P mobility in soil is very restricted 
due to its strong retention by soil oxides and clay minerals. Soil application of P fertilizers generally results in poor availability and utilization efficiency because $\mathrm{P}$ ions rapidly undergo precipitation and adsorption reactions in the soil. Also, under calcareous conditions, P is readily fixed (Papadopoulos \& Ristimaki, 1998). K has less mobility than $\mathrm{N}$ but higher mobility than $\mathrm{P}$. Therefore, its availability in conventional fertilizer treatment was relatively higher than $\mathrm{P}$ but lower than that under fertigation treatments (Figure 2).

Fertigation by Hydraulic injector or By-pass tank gradually increased the amount of available nutrients; the highest was in using Hydraulic injector followed by using By-pass tank. However, if there is a large amount of water entering and passing through the soil root zone, $\mathrm{N}$ can be carried by percolating water beyond the soil root zone. Therefore, it is recommended to apply nitrogen with small amount every irrigation time for better efficient use (Sharma et al., 2012). Available K is also increased under fertigation treatments might be due to the ability of soil to retain K and its low mobility in soils. Drip irrigation distributes K, allowing more uniform spreading of the $\mathrm{K}$ in the wetted volume of soil. Application of $\mathrm{P}$ through the irrigation water as phosphoric acid is recommended (Rauschkolb et al., 1976). Using phosphoric acid as $\mathrm{P}$ source through fertigation resulted in acidification which may create higher solubility of nutrients and movement of especially P and K (Almadini et al., 2006). The $\mathrm{P}$ concentration at the end of experiment for Sacchari and Madjool sites is lower than $\mathrm{P}$ concentration before starting the study because it consumed by these cultivars to provide the fruits with elements.

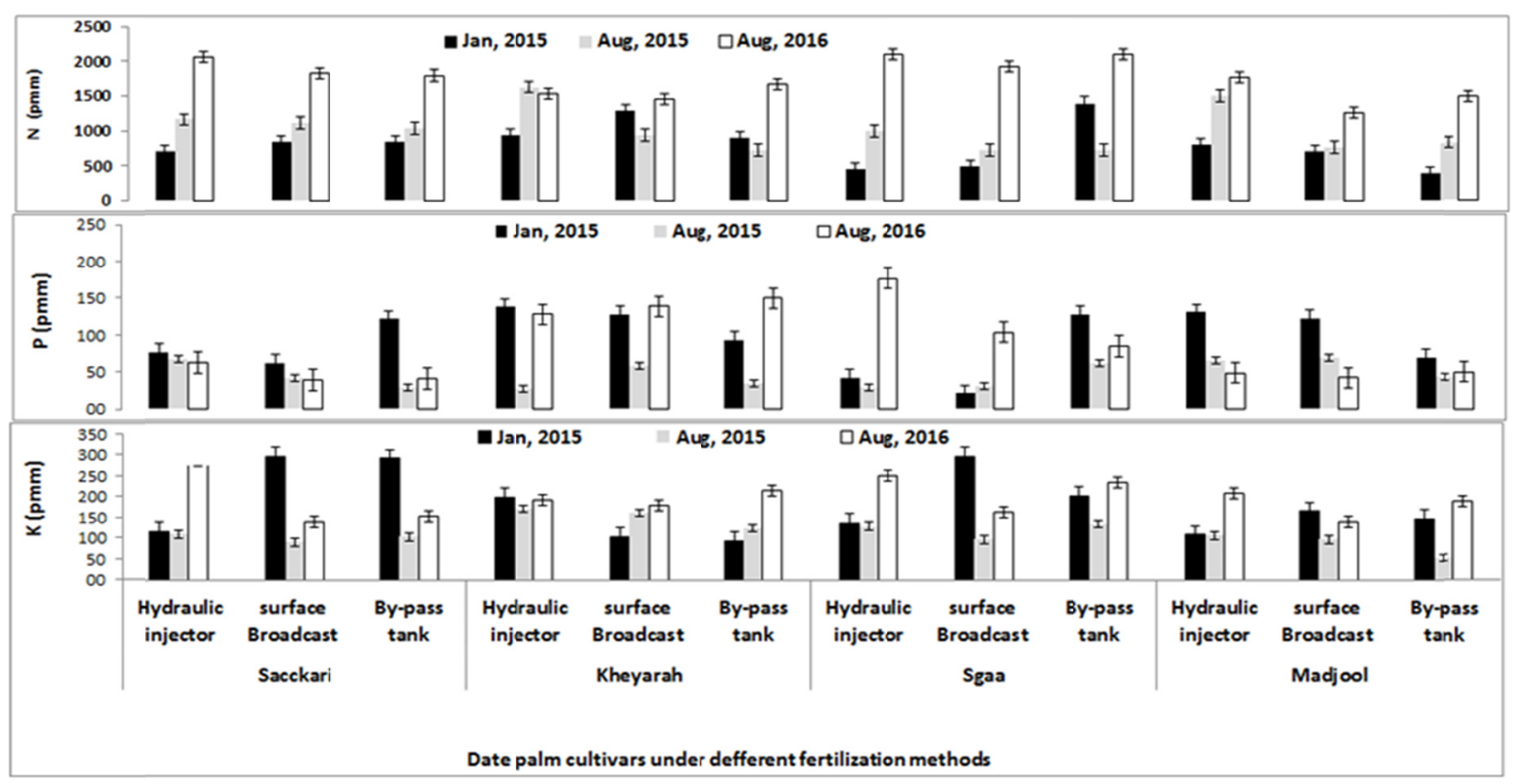

Figure 2. Nutrient concentration in soil samples collected from 0-50 cm depths for the studied date palm cultivars sites as affected by fertigation methods before starting and at harvesting stage of 2015 and 2016 growing seasons

\subsection{Leaf and Fruit Mineral Content}

The concentration of N, P and $\mathrm{K}$ in the leaves and fruits are presented in Figure 3. Leaves tissues mineral content were not affected by the fertilization methods. However, in fruit, the highest $\mathrm{N}$ concentration was recorded when using Hydraluic injector which was significantly higher than that in Broadcasting for all date palm cultivars. Fruit $\mathrm{P}$ and $\mathrm{K}$ concentrations were not significantly affected by the application methods. This is because the fertilizer distribution and availability is more than the other two methods that reflected the crop yield, so more fertilizer were absorbed. This result agree with Sayed and Bedaiwy (2011) whose found that under traditional application conditions, nitrification rates in soils. Results clearly revealed that fertigation using Hydraulic injector increased the availability of nutrients especially $\mathrm{P}$ (Figure 3) without, however, a further increase in either leaves or fruit tissues, instead of Hydraulic injector treatment that showed higher $\mathrm{N}$ concentration of fruit than that in Surface Broadcast (Figure 3). 
The leaf $\mathrm{P}$ contents were greater with using Hydraulic injector than with using Broadcasting and By-pass methods for Madjool, Sacchari and Kheyarah cultivars (Figure 3), similar results were reported by Al-Qurashi et al. (2015) by which they indicated that the fertigation treatments increased yield/palm up to $41 \%$, and saved $66 \%$ of the applied fertilizers compared with conventional treatment.

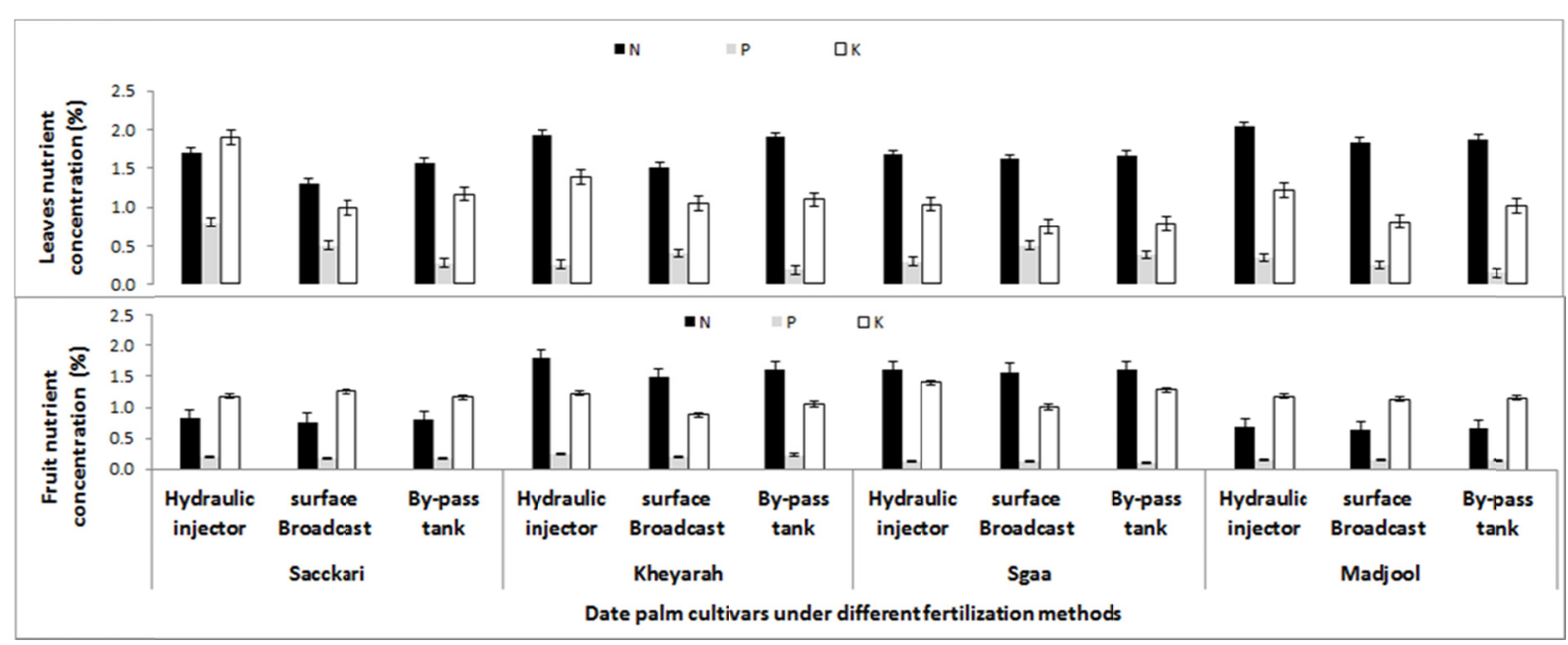

Figure 3. Nutrient concentration (\%) in leaves and fruits for four date palm cultivars as affected by fertilization methods

The results of the study (Figure 3) showed that there are no significant differences between fruit N, K and P contents with using the different fertilizer application methods, but when taking the yield per tree in the accounts, again using the Hydraulic injector is significantly increased the total fruit nutrients contents per tree more than Broadcasting or By-pass tank fertilization methods in all studied date palm cultivars.

\subsection{Total Fruit Sugar Content}

Fruit sugar percentage was significantly increased in all date palm cultivars by using Hydraulic injector fertigation as compared with Broadcasting and By-pass methods (Figure 4). Statistically, treatments showed no significant differences with each other except for the Surface Broadcast method. Although, from the numeral viewpoint, Hydraulic injector was caused the highest fruit sugar concentration with an increase of about $17 \%$ in comparison with using of the traditional Surface Broadcast method for Sggaa cultivar. Injection of fertilizer using Hydraulic injector, not only supplies enough amounts of available micro elements for photosynthesis, but also improves absorption and translocation of other nutrient elements such as Manganese and $\mathrm{P}$ by reducing the pH of sap (Taiz \& Zeiger, 1998). Therefore, it seems reasonable that injection Hydraulic injector works better than Broadcasting and By-pass fertilization methods. 


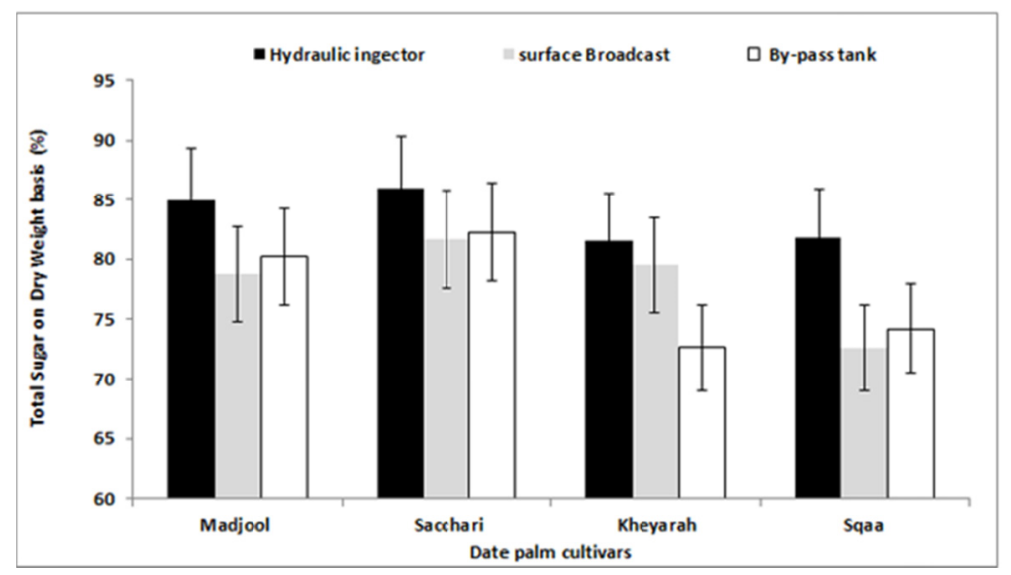

Figure 4. Fruit total sugar percentage for four date palm cultivars as affected by different fertilizers application methods

\section{Conclusions}

Results showed the superiority of the addition of fertilizers using the Hydraulic injector to traditional By-pass tank and Surface Broadcast methods, considering production or growth indicators. Also, the date palm Kheyarah cultivar showed a significant increase in production on the rest of the cultivars covered in the study for the two seasons. The obtained results during 2015 and 2016 growing seasons indicated that the highest yield was recorded for Sacchari cultivar of 67.3 and $70.6 \mathrm{~kg}_{\text {tree }}{ }^{-1}$ by using the Hydraulic injector fertigation method for the two growing seasons, respectively. While Madjool cultivar achieved the highest rate of weight of the fruit. Also, is not recommended to use the Broadcasting method because the soil of the UAE is sandy and the retention rate of fertilizer and water is very low.

\section{References}

Allen, R. G., Pereira, L. S., Raes, D., \& Smith, M. (1998). Crop evapotranspiration. Guidelines for computing crop water requirements (p. 300). FAO Irrigation and Drainage, Paper No. 56. FAO, Rome, Italy.

Almadini, A. M., El-Garawany, M. M., \& Masoud, M. A. (2006). Evaluating the soils Properties of the Agricultural and Veterinary Training and Research Station at KFU and Estimation Its Quality and Production Capability (Final Report No. 8089). Ahsa, Saudi Arabia: Deanship of Scientific Research, King Faisal University.

Al-Qurashi, A. D., Awad M. A., \& Saleh, M. M. S. (2015). Yield, Fruit Quality and Nutrient Uptake of 'Nabbut-Ahmar' Date Palm Grown in Sandy Loam Soil as Affected by NPK Fertigation. Journal of Plant Nutrition, 39(2), 268-278. https://doi.org/10.1080/01904167.2015.1043380

Al-Qurashi, A. D., Mohamed, A. A., \& Saleh, M. M. S. (2015). Growth, yield, fruit quality and nutrient uptake of tissue culture-regenerated 'Barhee' date palms grown in a newly established orchard as affected by NPK feritigation. Scientia Horticulturae, 184, 114-122. https://doi.org/10.1016/j.scienta.2014.12.034

Ashwani, K. (2001). Status of fertigation in India. In H. P. Singh, S. P. Kaushish, K. Ashwani, T. S. Murthy, \& J. C. Samuel (Eds.), Micro Irrigation (pp. 418-427). Central Board of Irrigation and Power, New Delhi.

Bazza, M. (2008). UAE country paper (pp. 75-81). Proceedings of Workshop on Irrigation of Date Palm and Associated Crops, in collaboration with the Faculty of Agriculture, Damascus University, Damascus, Syrian Arab Republic, FAO/RNE.

El Zuraiqi, S., Rusan, M. J., \& Al Qwasmi, W. (2004). Fertigation in Jordan. IPI regional workshop on potassium and fertigation development in West Asia and North Africa, Rabat, Morocco.

Fares, A., \& Abbas, F. (2009). Irrigation systems and nutrient sources for irrigation. University of Hawai'i at Mānoa, College of Tropical Agriculture and Human Resources, Publication SCM-25. Retrieved from http://www.ctahr.hawaii.edu/oc/freepubs/pdf/SCM-25.pdf 
Idris, T. I. M., Khidir, A. A., \& Haddad, M. A. (2012). Growth and yield responses of a dry date palm (Phoenix dactylifera L.) cultivar to soil and foliar fertilizers. International Research Journal of Agricultural Science and Soils, 2(9), 390-394.

Jaradat, A. A., \& Zaid, A. (2004). Quality traits of date palm fruits in a center of origin and center of diversity. Food, Agriculture and Environment, 2(1), 208-217.

Locascio, S. J., Olson, S. M., \& Rhoads, F. M. (1989). Water quantity and time of N and K application for trickle-irrigated tomatoes. J. Amer. Soc. Hort. Sci., 114, 265-268.

Neelam, P., \& Rajput, T. B. S. (2005). Effects of fertigation on growth and yield of onions. Indian J. Agric. Sci., 77(1), 725-730.

NSW Department of Primary Industries. (2005). Agriculture: Horticultural Fertigation-Techniques, Equipment and Management. State of New South Wales, Service NSW, Orange.

Papadopoulos, I. (1997a). Irrigation/fertigation modeling (pp. 79-90). In Proc. of the Intern. Conf. on "Water Management, Salinity and Pollution Control towards Sustainable Irrigation in the Mediterranean Region". CIHEAM, Bari, Italy.

Papadopoulos, I., \& Ristimaki, L. (1998). Nitrogen and phosphorus fertigation of tomato and eggplant. Proc. of the HIS, Belgium.

Patel, N. (2017). Precision Farming Development Centres Research Findings on Fertigation Techniques. National Seminaron Fertigation.

Patel, N., \& Rajput, T. B. S. (2004). Fertigation-A technique for efficient use of granular fertilizer through drip irrigation. I.E.I. Journal, 85, 50-54.

Priya, R. S., Kuttimani, C., Karthikeyan, R., \& Kuttimani, R. (2017). Drip Fertigation in Vegetable Crops for Enhancing Productivity and Resource Use Efficiency: An Overview. International Journal of Current Microbiology and Applied Sciences, 6(11), 3215-3230. https://doi.org/10.20546/ijcmas.2017.611.377

Rauschkolb, R. S., Rolston, D. E., Miller, R. J., Carlton, A., \& Burau, B. R. G. (1976). Phosphorus fertilization with drip irrigation. Soil Sci. Soc. Am. J., 40, 68-72. https://doi.org/10.2136/sssaj1976.036159950040000 $10021 \mathrm{x}$

Sayed, M. A., \& Bedaiwy, M. N. (2011). Effect of Controlled Sprinkler Chemigation on Wheat Crop in a Sandy Soil. Soil \& Water Res., 6(2), 61-72. https://doi.org/10.17221/10/2010-SWR

Taiz, L., \& Zeiger, E., (1998). Plant Physiology (2nd ed.). Sinauer, Sunderland.

Zaid, A., \& de Wet, P. F., (2002). Botanical and systematic description of the date palm. In A. Zaid, \& E. J. Arias-Jiménez (Eds.), Date Palm Cultivation (FAO Plant Production and Protection Paper 156 Rev. 1). Rome, Italy. Retrieved from http://www.fao.org/docrep/006/Y4360E/y4360e08.htm

Zotarelli, L., Dukes, M. D., Scholberg, J. M., Munoz-Carpena, R., \& Icerman, J. (2009). Tomato nitrogen accumulation and fertilizer use efficiency on a sandy soil, as affected by nitrogen rate and irrigation scheduling. Agric. Water Management, 96, 1247-1258. https://doi.org/10.1016/j.agwat.2008.06.007

\section{Copyrights}

Copyright for this article is retained by the author(s), with first publication rights granted to the journal.

This is an open-access article distributed under the terms and conditions of the Creative Commons Attribution license (http://creativecommons.org/licenses/by/4.0/). 